\title{
A new nos gene downstream from nosDFY is essential for dissimilatory reduction of nitrous oxide by Rhizobium (Sinorhizobium) meliloti
}

\author{
Yiu-Kwok Chan, Wayne A. McCormick and Robert J. Watson \\ Author for correspondence: Yiu-Kwok Chan. Tel: +1 613759 1663. Fax: + 16137591701. \\ e-mail: chanyk@em.agr.ca
}

Eastern Cereal and Oilseed Research Centre, Agriculture \& Agri-Food Canada, K. W. Neatby Bldg, Central Experimental Farm, 960 Carling Ave, Ottawa, Ontario, Canada K1A 0C6

\begin{abstract}
Rhizobium (Sinorhizobium) meliloti strains capable of dissimilatory nitrous oxide reduction (Nos') carry a nosRZDFY gene cluster on a 10.1 kb EcoRI fragment of the nod megaplasmid near the fixGHIS genes. These nos genes are arranged in three complementation groups and the $10.1 \mathrm{~kb}$ EcoRI fragment is sufficient to confer Nos activity to $R$. meliloti strains lacking such activity. An overlapping HindIII fragment containing the nosRZDFY genes but missing a $0.6 \mathrm{~kb}$ HindIII-EcoRI downstream segment was found incapable of imparting Nos activity to strains unable to reduce nitrous oxide, suggesting the presence of other nos gene(s) in this region. Tn5 introduced near the HindIII site resulted in mutants with a Nos' phenotype. Complete sequence analysis of nosY showed that it was well-conserved with respect to that of Pseudomonas stutzeri. Two previously unreported genes downstream of nos $Y$ in $R$. meliloti were also revealed. Contiguous with nos $Y$ was a sequence showing $63 \%$ identity with the ORFL protein of $P$. stutzeri. It appeared to be in the same operon as nosDFY and was predicted to encode a membrane lipoprotein similar to the putative NosL of P. stutzeri. Unlike the latter protein, however, amino acid sequences typical of metal-binding sites and cysteine residues indicative of the active site of protein disulphide isomerase were absent in the predicted NosL of $R$. meliloti. The Tn 5 mutations resulting in a Nos' phenotype were localized within a 966 nucleotide gene 31 nucleotides downstream of nosDFYL with the same orientation. The new gene, nosX, was determined to be in a separate complementation group. It encoded a periplasmic protein with homology in the C-terminal domain with RnfF of Rhodobacter capsulatus and with a hypothetical Escherichia coli protein, YOJK. It was concluded that there are seven genes constituting the nos cluster in $R$. meliloti. They are organized in four complementation groups and in the same orientation, spanning a distance of about $9 \mathrm{~kb}$ on the nod megaplasmid.
\end{abstract}

Keywords: Rhizobium (Sinorbizobium) meliloti, denitrification, nitrous oxide reduction, nos $Y L X$, lipoprotein

\section{INTRODUCTION}

The complete denitrification of nitrate by bacteria to dinitrogen $\left(\mathrm{N}_{2}\right)$ is generally an anaerobic respiratory process. The last step involves the dissimilatory reduction of nitrous oxide $\left(\mathrm{N}_{2} \mathrm{O}\right)$, the free energy change of which can be coupled to phosphorylation (Zumft,

The GenBank accession number for the nucleotide sequence reported in this paper is U94899.
1992; Zumft \& Kroneck, 1990). Denitrifying bacteria are ubiquitous in nature. Several species capable of partial or complete denitrification are $\mathrm{N}_{2}$-fixing bacteria, including those of the Rhizobiaceae family (Chan $e t$ al., 1994). One of these is Rhizobium meliloti (Chan et al., 1989), a bacterium that enters into symbiotic partnership with alfalfa by inducing the formation of root nodules on the plant. [R. meliloti was recently renamed Sinorbizobium meliloti (De Lajudie et al., 1994) but it is referred to as a Rhizobium species in this paper for consistency with our previous work.] Although an- 
Table 1. Bacterial strains and plasmids

\begin{tabular}{|c|c|c|}
\hline Strain or plasmid & Relevant characteristics* & Reference or source \\
\hline \multicolumn{3}{|l|}{ Strains } \\
\hline \multicolumn{3}{|l|}{ R. meliloti } \\
\hline $\mathrm{JJ} 1 \mathrm{c} 10$ & Wild-type strain $; \operatorname{Nos}^{+}$Rif $^{r}$ & Selvaraj et al. (1987) \\
\hline RmYC2160 & Spontaneous $\mathrm{Nal}^{\mathrm{r}} \mathrm{Rif}^{\mathrm{r}}$ derivative of BALSAC; $\mathrm{Nos}^{-} \mathrm{Nal}^{\mathrm{r}} \mathrm{Rif}^{\mathrm{r}}$ & Chan \& Wheatcroft (1993) \\
\hline RmYC2164 & Spontaneous $\mathrm{Nal}^{\mathrm{r}}$ derivative of ATCC $9930 ; \mathrm{Nos}^{-} \mathrm{Nal}^{\mathrm{r}} \mathrm{Rif}^{\mathrm{r}}$ & Chan \& Wheatcroft (1993) \\
\hline $\left.\begin{array}{l}\text { RmWM1181 } \\
\text { RmWM1182 } \\
\text { RmWM1183 } \\
\text { RmWM1195 }\end{array}\right\}$ & $\begin{array}{l}\text { nos } X:: \operatorname{Tn} 5-703, \operatorname{nos} X:: \operatorname{Tn} 5-A 43, \operatorname{nos} X:: \operatorname{Tn} 5-B 93, \operatorname{nos} X:: \operatorname{Tn} 5-7100, \mathrm{JJ} 1 \mathrm{c} 10 \\
\text { derivatives with genomic Tn5 inserts introduced by recombination; } \\
\text { Nos }^{-} \mathrm{Rif}^{\mathrm{r}} \mathrm{Km}^{\mathrm{r}}\end{array}$ & This report \\
\hline RmWM1192 & $\begin{array}{l}\text { nos } D: \text { : Tn } 5-B 90, \mathrm{JJ} 1 \mathrm{c} 10 \text { derivative with genomic } \mathrm{Tn} 5 \text { inserts introduced by } \\
\text { recombination; } \operatorname{Nos}^{-} \mathrm{Rif}^{\mathrm{r}} \mathrm{Km}^{\mathrm{r}}\end{array}$ & Holloway et al. (1996) \\
\hline $\left.\begin{array}{l}\text { RmWM1186 } \\
\text { RmWM1190 }\end{array}\right\}$ & $\begin{array}{l}\text { nos } F:: \operatorname{Tn} 5-A 28, \text { nosF }:: \operatorname{Tn} 5-B 13, \mathrm{JJ} 1 \mathrm{c} 10 \text { derivatives with genomic } \mathrm{Tn} 5 \text { inserts } \\
\text { introduced by recombination; } \text { Nos }^{-} \mathrm{Rif}^{\mathrm{r}} \mathrm{Km}^{\mathrm{r}}\end{array}$ & Holloway et al. (1996) \\
\hline $\begin{array}{l}\text { RmWM1184 } \\
\text { RmWM1191 }\end{array}$ & $\begin{array}{l}\text { nosR:: } \operatorname{Tn} 5-878, \text { nosR }:: \operatorname{Tn} 5-\mathrm{B} 42, \mathrm{JJ} 1 \mathrm{c} 10 \text { derivatives with genomic Tn5 inserts } \\
\text { introduced by recombination; Nos } \mathrm{Rif}^{r} \mathrm{Km}^{\mathrm{r}}\end{array}$ & Holloway et al. (1996) \\
\hline $\begin{array}{l}\text { RmWM1185 } \\
\text { RmWM1194 }\end{array}$ & $\begin{array}{l}\text { nos } Z:: \operatorname{Tn} 5-893, \text { nos } Z:: \operatorname{Tn} 5-C 11, \mathrm{JJ} 1 \mathrm{c} 10 \text { derivatives with genomic } \mathrm{Tn} 5 \text { inserts } \\
\text { introduced by recombination; } \operatorname{Nos}^{-} \mathrm{Rif}^{\mathrm{r}} \mathrm{Km}^{\mathrm{r}}\end{array}$ & Holloway et al. (1996) \\
\hline $\begin{array}{l}\text { RmWM1179 } \\
\text { RmWM1188 } \\
\text { RmWM1189 }\end{array}$ & $\begin{array}{l}\mathrm{JJ} 1 \mathrm{c} 10:: \operatorname{Tn} 5-7 C 35, \mathrm{JJ} 1 \mathrm{c} 10:: \operatorname{Tn} 5-A 52, \mathrm{JJ} 1 \mathrm{c} 10:: \operatorname{Tn} 5-B 4, \text { genomic } \operatorname{Tn} 5 \text { inserts } \\
\text { introduced by recombination; } \operatorname{Nos}^{+} \mathrm{Rif}^{\mathrm{r}} \mathrm{Km}^{\mathrm{r}}\end{array}$ & Holloway et al. (1996) \\
\hline \multicolumn{3}{|l|}{ E. coli } \\
\hline DH $5 \alpha$, HB101 & Host strains & $\begin{array}{l}\text { Boyer \& Roulland- } \\
\text { Dussoix (1969); Hanahan } \\
\text { (1983) }\end{array}$ \\
\hline \multicolumn{3}{|l|}{ Plasmids } \\
\hline pYC7 & $\begin{array}{l}\text { Cosmid pVK100 carrying contiguous } 8 \text { and } 14.5 \mathrm{~kb} \text { HindIII fragments } \\
\text { containing the nos region of } R \text {. meliloti JJ1c10; Tc }{ }^{r}\end{array}$ & Holloway et al. (1996) \\
\hline pYC8 & $\begin{array}{l}\text { Cosmid pVK100 carrying contiguous } 14.5 \text { and } 10.5 \mathrm{~kb} \text { HindIII fragments } \\
\text { containing a major nos region of } R \text {. meliloti } \mathrm{JJ} 1 \mathrm{c} 10 ; \mathrm{Tc}^{\mathrm{r}}\end{array}$ & This report \\
\hline pWM4 & $\begin{array}{l}\text { Broad-host-range plasmid pPW11 carrying the } 10 \cdot 1 \mathrm{~kb} \text { EcoRI fragment of } \mathrm{pYC7} \\
\text { including the entire nos region; } \mathrm{Tc}^{\mathrm{r}}\end{array}$ & Holloway et al. (1996) \\
\hline pWM5 & $\begin{array}{l}\text { Broad-host-range plasmid pRK310 carrying the } 14.5 \mathrm{~kb} \text { HindIII fragment of } \\
\text { pYC7; Tc }{ }^{r}\end{array}$ & Holloway et al. (1996) \\
\hline pWM1249 & $\begin{array}{l}3.0 \mathrm{~kb} \text { Pst I fragment carrying the } 3^{\prime} \text {-end of nosL, nos } X \text { and its downstream } \\
\text { region in pGEM-5Zf(+) (Promega); Ap }{ }^{r}\end{array}$ & This report \\
\hline pBB155 & $10 \cdot 1 \mathrm{~kb}$ EcoRI fragment of pYC7 carrying the entire nos region in $\mathrm{pUC} 19 ; \mathrm{Ap}^{\mathrm{r}}$ & Holloway et al. (1996) \\
\hline pBB149 & $\begin{array}{l}2.4 \mathrm{~kb} E c o \mathrm{R} 1-S p h \mathrm{I} \text { fragment from } \mathrm{pBB} 155 \text { including the } 3 \text {-end of nosY and } \\
\text { nosLX in pUC19; } \mathrm{Ap}^{\mathrm{r}}\end{array}$ & Holloway et al. (1996) \\
\hline pBB154 & $\begin{array}{l}1.5 \mathrm{~kb} \text { EcoR1-PstI fragment from } \mathrm{pBB} 155 \text { including the } 3^{\prime} \text {-end of nosL and } \\
n o s X \text { in pUC19; } \mathrm{Ap}^{\mathrm{r}}\end{array}$ & This report \\
\hline pRK2013 & $\begin{array}{l}\text { ColE1 replicon carrying } \mathrm{RK} 2 \text { transfer genes, helper plasmid for triparental } \\
\text { matings; } \mathrm{Km}^{\mathrm{r}}\end{array}$ & Figurski \& Helinski (1979) \\
\hline pRK600 & pRK2013::Tn9 derivative, helper plasmid for triparental matings; $\mathrm{Cm}^{\mathrm{r}}$ & Finan et al. (1986) \\
\hline pVK100 & Broad-host-range cosmid cloning vehicle; $\mathrm{Km}^{\mathrm{r}} \mathrm{Tc}^{\mathrm{r}}$ & Knauf \& Nester (1982) \\
\hline
\end{tabular}

*Ap ${ }^{r}$, ampicillin resistance $\left(50 \mu \mathrm{g} \mathrm{ml}^{-1}\right) ; \mathrm{Cm}^{\mathrm{r}}$, chloramphenicol resistance $\left(15 \mu \mathrm{g} \mathrm{ml}^{-1}\right) ; \mathrm{Km}^{\mathrm{r}}$, kanamycin resistance $\left(20 \mathrm{or}^{-10 \mu \mathrm{g} \mathrm{ml}}{ }^{-1}\right)$; $\mathrm{Nal}^{\mathrm{r}}$, nalidixic acid resistance $\left(10 \mu \mathrm{g} \mathrm{ml}^{-1}\right) ; \mathrm{Tc}^{\mathrm{r}}$, tetracycline resistance $\left(5\right.$ or $\left.10 \mu \mathrm{g} \mathrm{ml}^{-1}\right)$; Rifr, rifampin resistance $\left(100 \mu \mathrm{g} \mathrm{ml}{ }^{-1}\right)$.

aerobic nitrate respiration has been suggested to be indirectly controlled by fixLJ genes in rhizobia (Hennecke et al., 1993) and the nitrite reductase gene of an unclassified Rhizobium sp. has recently been characterized (Toffanin et al., 1996), the detailed investigation of denitrification genetics in this group of bacteria has largely been limited to $\mathrm{N}_{2} \mathrm{O}$ respiration.
Strains of $R$. meliloti capable of dissimilatory $\mathrm{N}_{2} \mathrm{O}$ reduction carry a gene cluster, nosRZDFY, located on the nod megaplasmid downstream from the fixGHIS genes (Chan \& Wheatcroft, 1993; Holloway et al., 1996). To date, the plasmid location of denitrification genes has been reported in only one other free-living denitrifier, Alcaligenes eutrophus (Friedrich et al., 1990). 
The nosRZDFY genes are known to be required for $\mathrm{N}_{2} \mathrm{O}$ reduction (Nos) activity in the well-studied denitrifier Pseudomonas stutzeri (Cuypers \& Zumft, 1992) and other free-living denitrifiers (Zumft et al., 1992): $\operatorname{nos} R$ is regulatory in function, nos $Z$ is the structural gene for the periplasmic $\mathrm{N}_{2} \mathrm{O}$ reductase, and nosDFY are genes for processing its copper cofactor. These plasmid-borne nos genes of $R$. meliloti have been shown by nucleotide sequence determination of nos $Z$ and its flanking regions to show a similar genetic sequence and organization to the chromosomal nosRZDFY genes of P. stutzeri (Holloway et al., 1996). They are arranged in three adjacent complementation groups located on a $10 \cdot 1 \mathrm{~kb}$ EcoRI fragment which is sufficient to confer Nos activity to $R$. meliloti strains completely lacking denitrification ability or specifically lacking Nos activity (Holloway et al., 1996). In the same study, plant tests with some nos mutants constructed by Tn5 insertions in the nos region did not show any effect on symbiotic $\mathrm{N}_{2}$ fixation activity. Hence, the nos genes concerned are probably not associated with the fix genes in their vicinity.

Further analysis of cosmids covering the known nos region in $R$. meliloti has led us to identify a novel gene, nosX, which has not been reported in any other denitrifier. It was detected on a previously unmapped region bearing a $0.6 \mathrm{~kb}$ HindIII-EcoRI fragment downstream from nosDFY. Analysis of new nos mutations generated by $\operatorname{Tn} 5$ insertions in this region indicated that they were in a complementation group distinct from the three groups consisting of nosRZDFY (Holloway et al., 1996). In addition, we have determined between nos $Y$ and nos $X$ a nosL sequence resembling the recently sequenced ORFL in P. stutzeri (Dreusch et al., 1996). Here, we describe these new findings and compare the sequences of the nos $Y L$ genes and their translated amino acid sequences with those of $P$. stutzeri.

\section{METHODS}

Bacterial strains, media and culture conditions. Bacterial strains and plasmids used in this work are listed in Table 1. $R$. meliloti strains were grown on TYC (tryptone-yeast extractcalcium) medium (Fallik et al., 1991) at $30^{\circ} \mathrm{C}$. Escherichia coli strains were grown in Luria-Bertani medium (Sambrook et al., 1989) at $37^{\circ} \mathrm{C}$. Antibiotics used were ampicillin $\left(50 \mu \mathrm{g} \mathrm{ml}^{-1}\right)$, chloramphenicol $\left(15 \mu \mathrm{g} \mathrm{ml}^{-1}\right)$, kanamycin (20 or $40 \mu \mathrm{g} \mathrm{ml}^{-1}$ ), nalidixic acid $\left(10 \mu \mathrm{g} \mathrm{ml}^{-1}\right)$, tetracycline (5 or $\left.10 \mu \mathrm{g} \mathrm{ml}^{-1}\right)$ and rifampin $\left(100 \mu \mathrm{g} \mathrm{ml}^{-1}\right)$. R. meliloti strains RmYC2160 and RmYC2164 are Nal ${ }^{r}$ derivatives of the Nos strains BALSAC and ATCC 9930, respectively, used as conjugation recipients.

Bacterial conjugation and molecular techniques. Tripartite matings involving helper plasmids (pRK2013 or pRK600) were used to introduce plasmids from $E$. coli to $R$. meliloti according to Ditta et al. (1980). DNA manipulations, including restriction digests, analysis by agarose gel electrophoresis, ligation and transformation, were carried out by standard methods (Sambrook et al., 1989). Tn5 mutagenesis of cosmid pYC7 and subsequent complementation analysis of the constructed $R$. meliloti JJ1c10 mutants were done as previously described (Holloway et al., 1996). Southern hybridization was performed with DNA probes labelled with
digoxigenin-11-dUTP (Boehringer Mannheim) by random priming. Hybrid DNA was detected by using chemiluminescent digoxigenin antibodies from the same manufacturer according to Holloway et al. (1996). Other genetic manipulations have been described previously (Chan \& Wheatcroft, 1993; Wu et al., 1995).

Gene sequencing. DNA sequence determination by the dideoxynucleotide chain-termination method of Sanger $e t$ al. (1977) was performed with a T7 sequencing kit (Pharmacia Biotech) or a Sequenase T7 polymerase kit (US Biochemical), and with ${ }^{33} \mathrm{P}$ - or ${ }^{35} \mathrm{~S}$-labelled dATP (Amersham). It was carried out on nested deletions generated from pWM1249 (Erase-aBase System, Promega), pBB149 and pBB154 (Exo-Size deletion kit, New England Biolabs). Both complementary strands of the DNA were sequenced. SP6 and T7 promoter primers (Promega) were used on the pWM1249 deletions; M13 universal and reverse primers (US Biochemical) were used on the pBB149 and pBB154 deletions. Gaps in the sequence were filled by using custom synthetic primers (Bio/Can Scientific or Canadian Life Technologies). Additional sequencing was done with a Sequitherm Cycle sequencing kit (Epicentre Technologies), following the manufacturer's instructions. Sequence data were assembled and analysed with PC/Gene software (IntelliGenetics).

Activity assay. $\mathrm{N}_{2} \mathrm{O}$ reduction was assayed in anaerobic $R$. meliloti cultures and its specific activity determined as described previously (Holloway et al., 1996).

\section{RESULTS AND DISCUSSION}

\section{Evidence for an extended nos region downstream from nOSRZDFY}

We have previously described $\mathrm{pYC7}$ as a cosmid clone of $R$. meliloti JJ1c10 DNA carrying the complete nos region near the centre of the inserted DNA on a $10 \cdot 1 \mathrm{~kb}$ EcoRI fragment (Holloway et al., 1996). An overlapping cosmid from the same genomic library, pYC8, was also identified using a nos $Z$ probe as carrying the nos region on a common $14.5 \mathrm{~kb}$ HindIII fragment. pYC8 carried $94 \%$ of the $10 \cdot 1 \mathrm{~kb}$ EcoRI fragment in the overlapping region, lacking only a $0.6 \mathrm{~kb}$ EcoRI-HindIII fragment at the end proximal to the fixLJKNOQPGHIS cluster downstream from the nosRZDFY genes (Fig. 1). How-

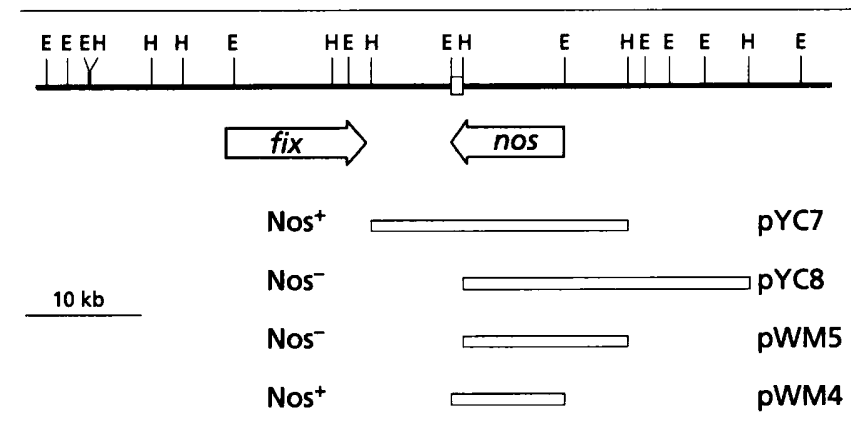

Fig. 1. Partial restriction map of the $R$. meliloti nod megaplasmid in the region of the nos and fix gene clusters. The boxed area indicates the newly extended nos region. Genes fixL, fixK, fixNOQP and fixGHIS are included in the fix cluster (Fischer, 1994). The range of $R$. meliloti DNA carried in cosmids (pYC7, pYC8) and broad-host-range plasmids (pWM4, pWM5) are shown with their ability to confer Nos activity to Nos backgrounds. E, ECoRI; H, HindllI. 


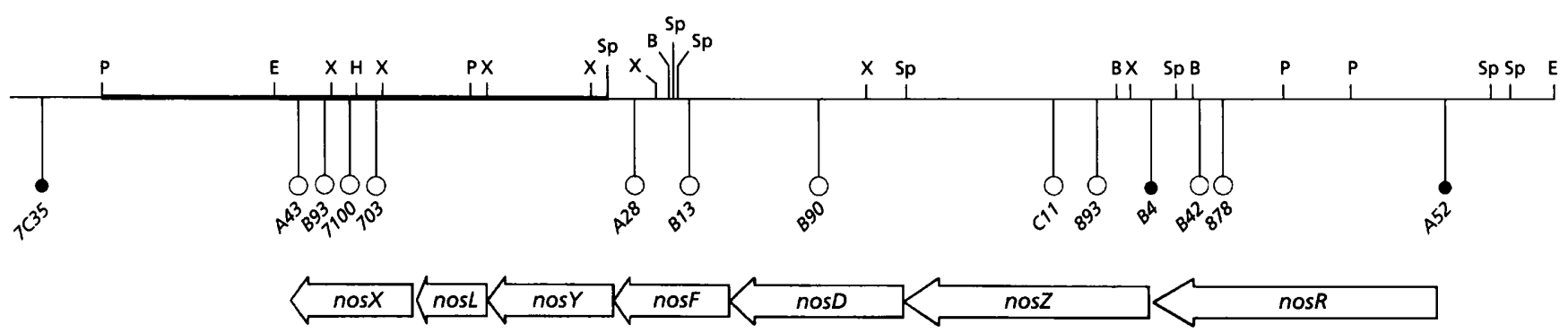

pBB149

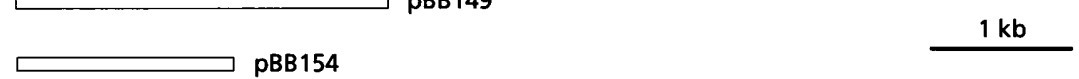

pWM1249

Fig. 2. Physical map of the complete nos gene region required for $\mathrm{N}_{2} \mathrm{O}$ reduction by $R$. meliloti. Tn5 insertions resulting in a Nos- phenotype are marked by open circles; insertions not affecting the Nos phenotype are marked by filled circles. Labelled arrows indicate the transcriptional direction of the individual genes. The thick line indicates the extent of nucleotide sequence determination. Clones used for the sequencing are shown at the bottom. B, BamHI; E, EcoRI; H, HindIII; P, Pstl; Sp, Sphl; X, Xhol.

ever, while pYC7 was able to confer the Nos ${ }^{+}$phenotype to R. meliloti $\mathrm{Rm} 2160$ and $\mathrm{Rm} 2164$ (Table 1), strains naturally lacking the entire nos region (Chan \& Wheatcroft, 1993), pYC8 was unable to do so, apparently because it did not carry the complete $10 \cdot 1 \mathrm{~kb}$ EcoRI fragment. The requirement for the $0.6 \mathrm{~kb}$ EcoRI-HindIII fragment was confirmed by testing the Nos phenotypes conferred by the broad-host-range plasmids pWM4 (carrying the complete $10 \cdot 1 \mathrm{~kb}$ EcoRI fragment only) and pWM5 (carrying the $14.5 \mathrm{~kb}$ HindIII fragment common to both pYC7 and pYC8). Only pWM4 was able to confer Nos activity, indicating the presence of other nos gene(s) in the vicinity of the $0.6 \mathrm{~kb}$ EcoRI-HindIII fragment downstream from nosRZDFY.

\section{Tn5 mutagenesis and nucleotide sequence of nos $Y L X$}

To examine the region downstream of nosDFY, Tn5 insertions in cosmid pYC7 were obtained and those mapping in the vicinity of the $0.6 \mathrm{~kb}$ EcoRI-HindIII segment were analysed. Four mutants with $\operatorname{Tn} 5$ insertions mapping near the HindIII site were derived. Consistent with the analysis of pYC8 described above, three of these insertions ( $A 43, B 93$ and 7100$)$ were localized within the $0.6 \mathrm{~kb}$ EcoRI-HindIII fragment while the fourth (703) was located within the adjacent $0.2 \mathrm{~kb}$ HindIII-XhoI fragment (Fig. 2). Despite repeated efforts, we were unable to obtain mutants with insertions in the $2 \mathrm{~kb}$ segment including the nos $Y$ gene and the region immediately downstream. When cosmids containing the four $\operatorname{Tn} 5$ insertions were introduced into a Nos ${ }^{-}$background (RmYC2160 or RmYC2164), they were unable to confer Nos activity, although the parental cosmid, pYC7, was able to do so. Consequently, these insertions confirm the extension of the known nos region from 74 to $90 \%$ of the $10 \cdot 1 \mathrm{~kb}$ EcoRI fragment.
To identify potential genes within the extended nos region, three overlapping fragments were cloned in pBB149, pBB154 and pWM1249 (Table 1; Fig. 2) for sequencing. In this terminal nos region two ORFs were found orientated in the same direction as nos $Y$ (Fig. 2). An ORF contiguous with nos $Y$ was homologous to the recently reported ORFL of $P$. stutzeri (Dreusch et al., 1996), while the other was new and unidentified. Since the region in which additional $\operatorname{Tn} 5$ insertions near the HindIII site (resulting in the loss of Nos phenotype) is covered by the new ORF, the latter is a functional gene which we named nosX.

\section{The nos $Y L$ genes and their products}

Sequence determination of the $5^{\prime}$ end of nos $Y$ has shown that its ATG start codon overlaps with the stop codon of the preceding nos $F$ gene within the sequence ATGA (Holloway et al., 1996). Complete sequencing of nos $Y$ revealed that it consists of 828 nucleotides encoding 275 amino acids. The sequence was $63 \%$ identical with the 831 nucleotide nos $Y$ gene of $P$. stutzeri, which also overlaps with the preceding nos $F$ gene and is believed to be involved in copper chromophore synthesis (Zumft $e t$ al., 1990). Its translated amino acid sequence showed an overall $47 \%$ identity with the 276 residue $P$. stutzeri NosY integral membrane protein. $R$. meliloti NosY was also a hydrophobic membrane protein, which contained $20 \%$ leucine residues and six transmembrane helices (at positions 21-37, 53-69, 109-125, 150-166, 176-192 and 250-266) as predicted by the methods of Eisenberg et al. (1984) and Klein et al. (1985). When juxtaposed, the remarkably similar hydropathy profiles and largely overlapping transmembrane segments of the two proteins are readily revealed (Fig. 3). However, unlike the $P$. stutzeri protein, a potential signal sequence cleavage site in the $R$. meliloti NosY was not apparent 


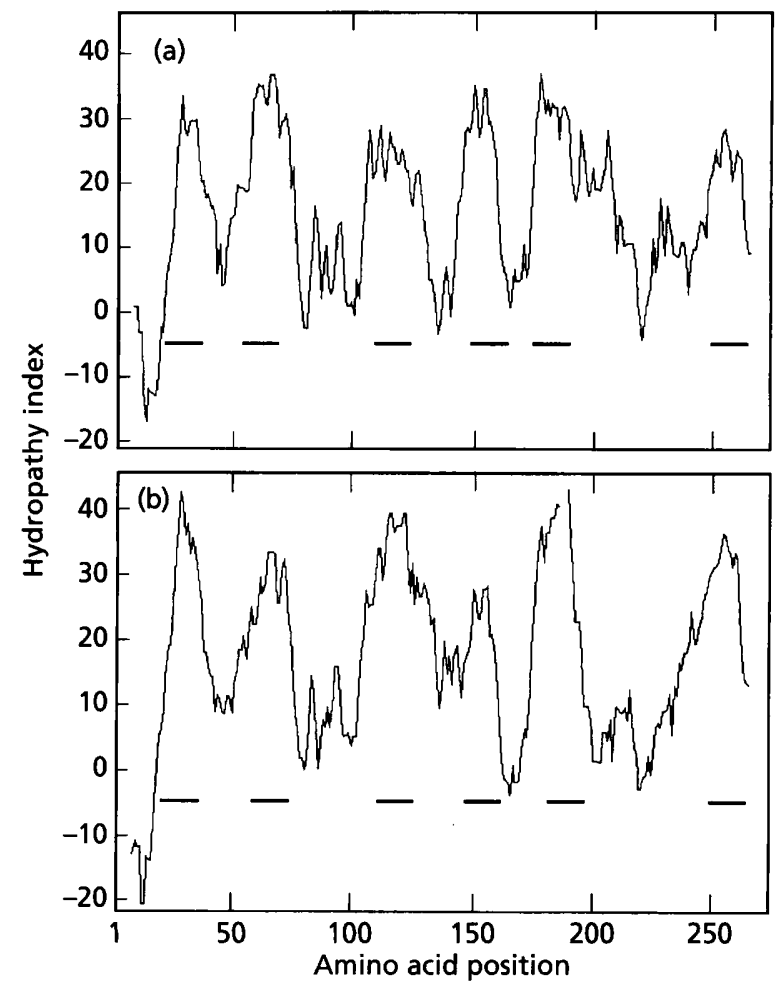

Fig. 3. Hydropathy profile of the predicted NosY protein of $R$. meliloti (a) juxtaposed with that of $P$. stutzeri (b). Computation was based on an interval of 15 amino acids (Kyte \& Doolittle, 1982). Horizontal bars indicate the positions of transmembrane segments (Klein et al., 1985).

according to the $-1-3$ rule (von Heijne, 1986). The single histidine (His-108) of the P. stutzeri NosY is conserved in that of $R$. meliloti, but the latter has an additional histidine (His-243). All of these histidines are located outside the transmembrane helices. However, while the two cysteine residues (Cys-122 and Cys-255) of the $P$. stutzeri protein reside within separate membrane helices (Zumft et al., 1990), the only cysteine residue in the $R$. meliloti counterpart (Cys-102) is located outside such helices. Because of their location, these residues are probably not metal ligands that would allow NosY to serve as a copper carrier in either organism. Nevertheless, NosY has been speculated to mediate between an energy-dependent copper-insertion process involving NosD in the periplasm and the energy-providing NosF at the cytoplasmic side of the inner membrane, as modelled after bacterial transport systems for small molecules (Zumft et al., 1990).

The partially overlapping arrangement of the start/stop codons in the consecutive nosDFY genes of $R$. meliloti (Holloway et al., 1996) continued in the nosY stop codon as it was also found to overlap with the start codon of the following ORF. This ORF was 558 nucleotides long and showed $63 \%$ identity with the 573 nucleotide ORFL of $P$. stutzeri (Dreusch et al., 1996). Since we were unsuccessful in obtaining Tn 5 insertions in the region between nosF and nos $X$ (Fig. 2), we could

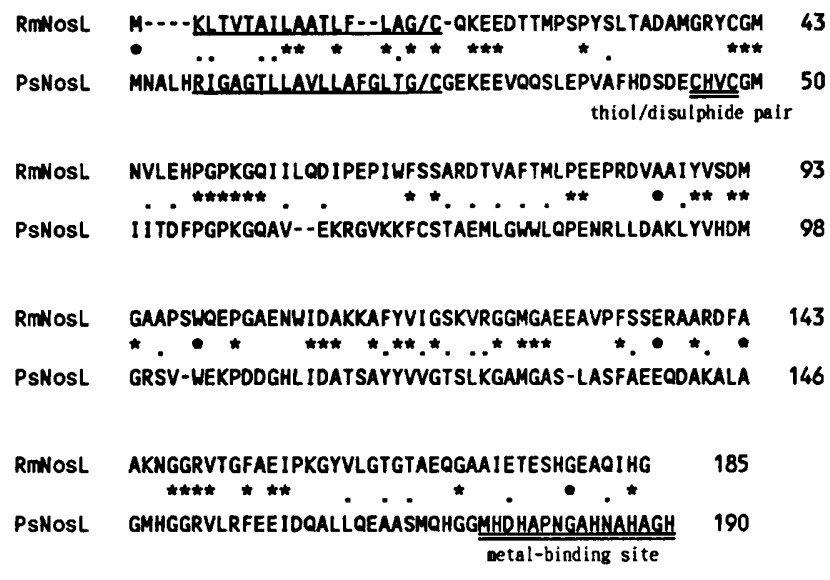

Fig. 4. Alignment of the NosL sequences of $R$. meliloti (Rm) and $P$. stutzeri (Ps). A slash in each underlined consensus lipoprotein signal peptide sequence denotes a cleavage site (Hayashi \& $\mathrm{Wu}, 1990$ ) according to the PROSITE program of PC/Gene. Unique signature sequences in P. stutzeri NosL (Dreusch et al., 1996) are double-underlined and labelled. An asterisk denotes identical amino acids; a dot, related amino acids. Amino acid residues are numbered on the right.

not definitively establish that nosDFYL belong to the same complementation group. However, the relatively close linkage of these genes in $R$. meliloti and their apparent lack of transcriptional terminators downstream of nos $Y$ suggest that the nosDFYL cluster in this organism represents genes belonging to one transcription unit. The organization of nosDFYL in $P$. stutzeri is somewhat different. Its ORFL is located 28 nucleotides downstream of nos $Y$ but still lacks a determinable transcription start site independent of the presumed nosDFY operon (Dreusch et al., 1996). Since the ORF is conserved between $P$. stutzeri and $R$. meliloti, it is likely that the sequence encodes a functional gene in both organisms.

R. meliloti JJ1c10 is the second denitrifying organism after $P$. stutzeri reported to possess a nosL-like gene. The derived amino acid sequence of the 185 residue $R$. meliloti NosL is $31 \%$ identical with the tentative 190 residue $P$. stutzeri NosL (Dreusch et al., 1996). Both gene products are predicted to be membrane lipoproteins. The 18 residue precursor signal peptide of $R$. meliloti NosL, which is six residues shorter than that of $P$. stutzeri, consists of one transmembrane helix $\left({ }^{2}\right.$ KLTVTAILAATLFLAGC $\left.{ }^{18}\right)$ at the $\mathrm{N}$ terminus (Fig. 4) with a predicted lipid attachment site located at the cysteine residue (Cys-18), qualifying NosL as an outermembrane lipoprotein (Hayashi \& Wu, 1990). In addition to the conserved location of the cysteine for lipid attachment and cleavage, the presequence in both signal peptides also conforms to the consensus pattern with one lysine or arginine residue in the first seven positions. However, both the $\mathrm{C}$-terminal signature sequence $\left({ }^{170} \mathrm{MXHXXMHXHX}{ }_{5} \mathrm{HXXHXXH}^{190}\right)$ of a potential metal-binding site and the $\mathrm{N}$-terminal activesite thiol/disulphide pair $\left({ }^{45} \mathrm{CHVC}^{50}\right)$ of a protein 
disulphide isomerase reported for the NosL of $P$. stutzeri (Dreusch et al., 1996) are not evident in the R. meliloti homologue (Fig. 4). Only two histidine residues, His178 and His-184, were found at the $\mathrm{C}$ terminus of the rhizobial product, where His- 184 could be a conserved residue. No potential metal-binding motifs in the sequence were identified. Of the thiol/disuphide pair (Cys-45 and Cys-48), only Cys-48 appears to be conserved. Hence, the product of nosL in R. meliloti is unlikely to be directly involved in metal-binding or to function as a protein disulphide isomerase. This implies that a non-specific protein disulphide isomerase encoded outside the nos region is required for the posttranslational maturation of the periplasmic $\mathrm{N}_{2} \mathrm{O}$ reductase. In P. stutzeri, an insertional mutation affecting the C-terminal domain of NosL had no detectable effect on the activity or synthesis of $\mathrm{N}_{2} \mathrm{O}$ reductase (Dreusch $e t$ al., 1996) and, therefore, may not strictly be regarded as a nos gene. Whether the mutation still permitted sufficient activity of NosL or its enzymic function was replaceable by a periplasmic disulphide isomerase in this organism has not been verified. Hence, the real function of the putative NosL, especially in $R$. meliloti, remains unclear and awaits further clarification.

\section{The nos $X$ gene and its product}

A 966 nucleotide ORF in the same orientation as nosDFYL was found 31 nucleotides downstream from the stop codon of nosL. Because of the abolition of Nos activity by the $\operatorname{Tn} 5$ insertions, it represented a functional gene, known here as nos $X$. Its $3^{\prime}$ end, which also marked the termination of the nos region, was located 96 nucleotides from the $E c o$ RI site at the end of $\mathrm{pBB} 149$ and pBB154 used for the sequence determination (Fig. 2).

Analysis of $\operatorname{nos} X$ showed that it encoded a peripheral membrane protein of 321 amino acids with one possible transmembrane helix (position 270-293) predicted by the method of Rao \& Argos (1986) toward its Cterminal domain, and a secretory leader sequence with a putative cleavage site detected between residue 31 and 32 that conformed to the $-1-3$ rule (von Heijne, 1986). NosX was found to exhibit about $27 \%$ (86 residues) sequence identity with $\mathrm{RnfF}$ of $R$ bodobacter capsulatus, a secretory membrane protein of 523 amino acids with a signal sequence of 44 amino acids (Schmehl et al., 1993). A majority (72\%) of the identical amino acids were located away from the $\mathrm{N}$-terminal domains of both NosX and RnfF. The NosX C terminus also showed similar homology (53 identical residues) with YOJK, an unpublished hypothetical $22 \cdot 1 \mathrm{kDa} E$. coli protein of unknown function (SWISS-PROT database accession number P33943). There is no significant identity between NosX and any of the putative ORF proteins derived from the $9.72 \mathrm{~kb}$ segment that links the nir-nor and nos gene clusters for denitrification in $P$. stutzeri (Glockner \& Zumft, 1996). Hence, an equivalent nos $X$ gene in the vicinity of nosL is not apparent in $P$. stutzeri, probably reflecting a species difference. A comparison of the consensus portion

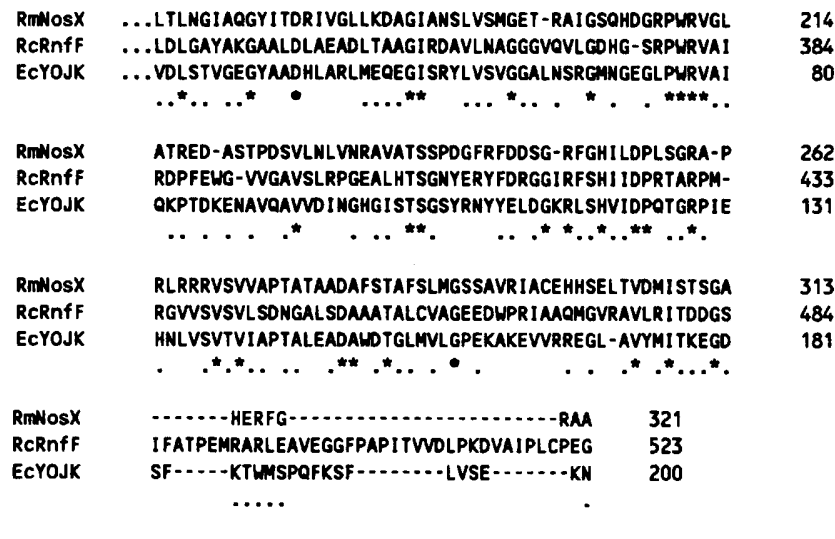

Fig. 5. Comparison of the $C$ termini of the $R$. meliloti $(\mathrm{Rm})$ NosX, R. capsulatus (Rc) RnfF and $E$. coli (Ec) YOJK proteins. Multiple alignment of the sequences was done by using the CLUSTAL programme of PC/Gene. An asterisk denotes identical amino acids; a dot, related amino acids. Amino acid residues are numbered on the right.

toward the $\mathrm{C}$ termini of NosX, RnfF and YOJK showed that $15 \%$ of the residues are identical and another $35 \%$ are well-conserved (Fig. 5). RnfF has been determined to be an iron-sulphur protein involved in electron transport to nitrogenase which is essential for diazotrophic growth (Schmehl et al., 1993). Its $\mathrm{N}$-terminal portion contains a cysteine motif $\left(\mathrm{C}-\mathrm{X}_{3}-\mathrm{C}-\mathrm{X}-\mathrm{C}-\mathrm{X}_{2}-\mathrm{C}\right)$ typical of $[4 \mathrm{Fe}-4 \mathrm{~S}]$ proteins. Since NosX contains only one cysteine residue (Cys-297), it obviously lacks cysteine motifs and is not an iron-sulphur protein. Although nos $X$ was demonstrated to be essential for $\mathrm{N}_{2} \mathrm{O}$ reduction, its function is presently unknown. It is not expected to be involved in $\mathrm{N}_{2}$ fixation since an $R$. meliloti strain with its entire nos region deleted was not affected in its Fix phenotype (Holloway et al., 1996). It will be important to know if nosX-like genes exist in other denitrifiers.

\section{Complementation analysis of the complete nos region}

Complementation analysis of the nos region was carried out to include the end of the $10 \cdot 1 \mathrm{~kb}$ EcoRI fragment downstream from nos Y by mating cosmids pYC7:: Tn 5A43, pYC7::Tn5-B93 and other previously selected pYC7:: Tn5 cosmids into JJ1c10 derivatives containing genomic insertions in the nos region (Table 2). $\mathrm{N}_{2} \mathrm{O}$ reduction assays of the transconjugants showed that nos $X$ was in a complementation group separate from $\operatorname{nos} R, \operatorname{nos} Z$ and $\operatorname{nos} D F(Y L)$ and, therefore, represented a different operon. It was noted that some of the complementation results using mutations in nos $X$ paired with mutations in nos $R$ were anomalous, particularly the results obtained using pYC7::Tn5-878. One explanation is that the nos $X$ product may interact with NosR, which is regulatory in function.

In the absence of $\operatorname{Tn} 5$ insertions in nos $Y$ and nosL, the present grouping of the nosDF $(Y L)$ genes is based on the 
Table 2. Complementation analysis of the $R$. meliloti nos region

Cosmid pYC7 carries the wild-type nos region. Each pYC7 derivative containing a $\operatorname{Tn} 5$ insertion was introduced into the $R$. meliloti nos mutant used as recipient and the transconjugants were tested for $\mathrm{N}_{2} \mathrm{O}$ reduction activity.

\begin{tabular}{|c|c|c|c|c|c|c|c|}
\hline \multirow[t]{2}{*}{ Recipient } & \multirow[t]{2}{*}{ Genotype } & \multicolumn{6}{|c|}{$\mathrm{N}_{2} \mathrm{O}$ reduction activity of $\mathrm{pYC7}:: \operatorname{Tn} 5$ transconjugants ${ }^{*}$} \\
\hline & & $\operatorname{Tn} 5-A 43$ & $\operatorname{Tn} 5-B 93$ & $\operatorname{Tn} 5-A 28$ & $\operatorname{Tn} 5-C 11$ & Tn5-B42 & $\operatorname{Tn} 5-878$ \\
\hline RmWM1182 & $\operatorname{nos} X:: \operatorname{Tn} 5-A 43$ & - & $(+)$ & + & + & + & - \\
\hline RmWM1183 & $\operatorname{nos} X:: \operatorname{Tn} 5-B 93$ & $(+)$ & - & + & + & + & - \\
\hline RmWM1195 & $n o s X:: \operatorname{Tn} 5-7100$ & - & - & + & + & + & - \\
\hline RmWM1181 & $n o s X:: \operatorname{Tn} 5-703$ & - & - & + & + & + & - \\
\hline RmWM1186 & nosF::Tn5-A28 & + & + & - & + & + & + \\
\hline RmWM1190 & nosF::Tn5-B13 & + & + & - & + & + & + \\
\hline RmWM1192 & nosD:: $\operatorname{Tn} 5-B 90$ & + & + & - & + & + & + \\
\hline RmWM1194 & nosZ::Tn5-C11 & + & + & + & - & + & + \\
\hline RmWM1185 & nos $Z:: \operatorname{Tn} 5-893$ & + & + & + & - & + & + \\
\hline RmWM1191 & $\operatorname{nos} R:: \operatorname{Tn} 5-B 42$ & + & $(+)$ & + & + & - & - \\
\hline RmWM1184 & nosR:: $\operatorname{Tn} 5-878$ & + & + & + & + & - & - \\
\hline RmWM1179† & Wild-type & + & + & + & + & + & + \\
\hline
\end{tabular}

$*+$, Wild-type activity [approx. $750 \mathrm{nmol} \mathrm{N}_{2} \mathrm{O}(\mathrm{mg} \text { protein })^{-1} \mathrm{~h}^{-1}$ ]; - , negative activity $(<10 \%$ of wild-type activity $) ;(+)$, delayed partial activity $(<50 \%$ wild-type activity after $>6 \mathrm{~h}$ incubation).

†The Tn5 insert in RmWM1179 (JJ1c10::Tn5-7C35) is outside the nos gene cluster.

overlapping start/stop codon arrangement of the individual genes. From these results and our previous observations (Holloway et al., 1996), we suggest that the nos genes of $R$. meliloti are organized in four complementation groups, spanning a distance of about $9 \mathrm{~kb}$ on the nod megaplasmid. All of these adjacent groups, namely, nosR, nos $Z$, nosDF(YL) and nosX, are transcribed in the same direction. The present findings serve as a basis for future investigations into the coordination of nos and other denitrification genes in rhizobia.

\section{ACKNOWLEDGEMENTS}

We thank Roselyn Heys for assistance in DNA sequence determination and Teresa Martin for helping in complementation analysis. We also appreciate the useful comments on the manuscript by Thérèse Ouellet and Laurian Robert. This paper is ECORC contribution number 971117.

\section{REFERENCES}

Boyer, H. W. \& Roulland-Dussoix, D. (1969). A complementation analysis of the restriction and modification of DNA in Escherichia coli. J Mol Biol 41, 459-472.

Chan, Y.-K. \& Wheatcroft, R. (1993). Detection of a nitrous oxide reductase structural gene in Rhizobium meliloti strains and its location on the nod megaplasmid of JJ1c10 and SU47. J Bacteriol 175, 19-26.

Chan, Y.-K., Barran, L. \& Bromfield, E. S. P. (1989). Denitrification activity of phage types representative of two populations of indigenous Rhizobium meliloti. Can J Microbiol 35, 737-740.

Chan, Y.-K., Barraquio, W. L. \& Knowles, R. (1994). $\mathrm{N}_{2}$-fixing pseudomonads and related soil bacteria. FEMS Microbiol Rev 13, 95-118.

Cuypers, H. \& Zumft, W. G. (1992). Regulatory components of the denitrification gene cluster of Pseudomonas stutzeri. In Pseudomonas: Molecular Biology and Biotechnology, pp. 188-197. Edited by E. Galli, S. Silver \& B. Witholt. Washington, DC: American Society for Microbiology.

De Lajudie, P., Willems, A., Pot, B., Dewettinck, D., Maestrojuan, G., Neyra, M., Collins, M. D., Dreyfus, B., Kersters, K. and Gillis, M. (1994). Polyphasic taxonomy of rhizobia: emendation of the genus Sinorbizobium and description of Sinorbizobium meliloti comb. nov., and Sinorbizobium teranga sp. nov. Int J Syst Bacteriol 44, 715-733.

Ditta, G., Stanfield, S., Corbin, D. \& Helinski, D. R. (1980). Broad host range DNA cloning system for Gram-negative bacteria: construction of a gene bank of Rhizobium meliloti. Proc Natl Acad Sci USA 77, 7347-7351.

Dreusch, A., Riester, J., Kroneck, P. M. H. \& Zumft, W. G. (1996). Mutation of the conserved Cys165 outside of the $\mathrm{Cu}_{\mathrm{A}}$ domain destabilizes nitrous oxide reductase but maintains its catalytic activity: evidence for disulfide bridges and a putative protein disulfide isomerase gene. Eur J Biochem 237, 447-453.

Eisenberg, D., Schwarz, E., Komaromy, M. \& Wall, R. (1984). Analysis of membrane and surface protein sequences with the hydrophobic moment plot. J Mol Biol 179, 125-142.

Fallik, E., Chan, Y.-K. \& Robson, R. L. (1991). Detection of alternative nitrogenases in aerobic gram-negative nitrogen-fixing bacteria. J Bacteriol 173, 365-371.

Figurski, D. H. \& Helinski, D. R. (1979). Replication of an origincontaining derivative of plasmid RK2 dependent on a plasmid function provided in trans. Proc Natl Acad Sci USA 76, 1648-1652.

Finan, T. M., Kunkel, B., Vos, G. F. D. \& Signer, E. R. (1986). Second symbiotic megaplasmid in Rhizobium meliloti carrying exopolysaccharide and thiamine synthesis genes. J Bacteriol 167, 66-72.

Fischer, H.-M. (1994). Genetic regulation of nitrogen fixation in rhizobia. Microbiol Rev 58, 352-386. 
Friedrich, B., Bocker, C., Eberz, G. \& 8 other authors (1990). Genes for hydrogen oxidation and denitrification form two clusters on megaplasmid pHG1 of Alcaligenes eutrophus. In Pseudomonas: Biotransformations, Pathogenesis, and Evolving Biotechnology, pp. 408-419. Edited by S. Silver, A. M. Chakrabarty, B. Iglewski \& S. Kaplan. Washington, DC: American Society for Microbiology.

Glockner, A. B. \& Zumft, W. G. (1996). Sequence analysis of an internal $9.72 \mathrm{~kb}$ segment from the $30 \mathrm{~kb}$ denitrification gene cluster of Pseudomonas stutzeri. Biochim Biophys Acta 1277, 6-12.

Hanahan, D. (1983). Studies on transformation of Escherichia coli with plasmids. J Mol Biol 166, 557-580.

Hayashi, S. \& Wu, H. C. (1990). Lipoproteins in bacteria. J Bioenerg Biomembr 22, 451-471.

von Heijne, G. (1986). A new method for predicting signal sequence cleavage sites. Nucleic Acids Res 14, 4683-4690.

Hennecke, H., Anthamatten, D., Babst, M. \& 8 other authors (1993). Genetic and physiologic requirements for optimal bacteroid function in the Bradyrhizobium japonicum soybean symbiosis. In Advances in Molecular Genetics of Plant-Microbe Interactions, vol. 2, pp. 199-207. Edited by E. W. Nester \& D. P. S. Verma. Dordrecht: Kluwer.

Holloway, P., McCormick, W., Watson, R. J. \& Chan, Y.-K. (1996). Identification and analysis of the dissimilatory nitrous oxide reduction genes, nosRZDFY, of Rhizobium meliloti. J Bacteriol 178, 1505-1514.

Klein, P., Kanehisa, M. \& DeLisi, C. (1985). The detection and classification of membrane-spanning proteins. Biochim Biophys Acta 815, 468-476.

Knauf, V. C. \& Nester, E. W. (1982). Wide host range cloning vectors: a cosmid clone bank of Agrobacterium Ti plasmid. Plasmid 8, 45-54.

Kyte, J. \& Doolittle, R. F. (1982). A simple method for displaying the hydropathic character of a protein. J Mol Biol 157, 105-132.

Rao, J. K. M. \& Argos, P. (1986). A conformational preference parameter to predict helices in integral membrane proteins. Biochem Biophys Acta 869, 197-214.

Sambrook, J., Fritsch, E. F. \& Maniatis, T. (1989). Molecular Cloning : a Laboratory Manual, 2nd edn. Cold Spring Harbor, NY: Cold Spring Harbor Laboratory.
Sanger, F., Nicklen, S. \& Coulson, A. R. (1977). DNA sequencing with chain-terminating inhibitors. Proc Natl Acad Sci USA 74, 5463-5467.

Schmehl, M., Jahn, A., zu Vilsendorf, A. M., Hennecke, S., Masepohl, B., Schuppler, M., Marxer, M., Oelze, J. \& Klipp, W. (1993). Identification of a new class of nitrogen fixation genes in Rhodobacter capsulatus: a putative membrane complex involved in electron transport to nitrogenase. Mol Gen Genet 241, 602-615.

Selvaraj, G., Hooper, I., Shantharam, S., lyer, V. N., Barran, L., Wheatcroft, R. \& Watson, R. J. (1987). Derivation and molecular characterization of symbiotically deficient mutants of Rhizobium meliloti. Can J Microbiol 33, 739-747.

Toffanin, A., Wu, Q., Maskus, M., Casella, S., Abruna, H. D. \& Shapleigh, J.P. (1996). Characterization of the gene encoding nitrite reductase and the physiological consequences of its expression in the nondenitrifying Rhizobium 'hedysari' strain HCNT1. Appl Environ Microbiol 62, 4019-4025.

Wu, Q., Knowles, R. \& Chan, Y.-K. (1995). Production and consumption of nitric oxide by denitrifying Flexibacter canadensis. Can J Microbiol 41, 585-591.

Zumft, W. G. (1992). The denitrifying prokaryotes. In The Prokaryotes, 2nd edn, pp. 554-582. Edited by A. Balows, H. G. Trüper, M. Dworkin, W. Harder \& K.-H. Schleifer. New York: Springer.

Zumft, W. G. \& Kroneck, P. M. H. (1990). Metabolism of nitrous oxide. In Denitrification in Soil and Sediment, pp. 37-55. Edited by N. P. Revsbech \& J. Sørensen. New York: Plenum Press.

Zumft, W. G., Viebrock-Sambale, A. \& Braun, C. (1990). Nitrous oxide reductase from denitrifying Pseudomonas stutzeri: genes for copper-processing and properties of the deduced products, including a new member of the family of ATP/GTP-binding proteins. Eur J Biochem 192, 591-599.

Zumft, W. G., Dreusch, A., Löchelt, S., Cuypers, H., Friedrich, B. \& Schneider, B. (1992). Derived amino acid sequences of the nos $Z$ gene (respiratory $\mathrm{N}_{2} \mathrm{O}$ reductase) from Alcaligenes eutrophus, Pseudomonas aeruginosa and Pseudomonas stutzeri reveal potential copper-binding residues: implications for the $\mathrm{Cu}_{\mathrm{A}}$ site of $\mathrm{N}_{2} \mathrm{O}$ reductase and cytochrome- $c$ oxidase. Eur J Biochem 208, $31-40$.

Received 24 February 1997; revised 24 April 1997; accepted 25 April 1997. 